\title{
ЗАРУБЕЖНАЯ ННФОРМАЦИЯ
}

\section{НАУЧНО-ИССЛЕДОВАТЕЛЬСКАЯ РАБОТА В НАНКИНСКОМ ПОЛИТЕХНИЧЕСКОМ ИНСТИТУТЕ}

\author{
(Радиотехнический факультет)
}

\begin{abstract}
Научно-исследовательская работа в Нанкинском политехническом институте начала планомерно развиваться после проведенной в 1955 г. под руководством Қоммунистической партии Қитая реформы высшего образования. В соответствин с требованиями социалистического строительства нашей страны, партия указала на необходимость тесной связи теории с практикой.
\end{abstract}

В основу научно-исследовательской работы радиотехнического факультета по опљту Советского Союза был положен принцип органического сочетания с производством It научно-педагогической работой. Практика подтвердила справедливость этого принципа: среди сравнительно большого количества исследовательских тем, поставленных на кафедрах нашего факультета, лучше всего были выполнены темы, связанные с производством и учебно-педагогической работой.

С 16 по 30 октября 1956 г. в Нанкинском политехническом институте состоялась первая сессия научной конференцин, на котороӥ было представлено 205 докладов и сообщений. Радиотехническим факультетом было представлено 14 работ.

1. Некоторые вопросы отрища̄тельной обратной связи.

2. О коэффициенте полезного действия генератора СВЧ, работающего в режиме С.

3. Проектирование цепей сопряжения днапазона высокой частоты в супергетеродннном прнемнике.

4. Анализ.І расчет амплитудных ограничителей.

5. Расчет режима генератора дециметровых волн.

6. Матричный анализ линейных цепей.

7. Анализ прохождения воздействия частично-синусондальных периодических импульсов через электрические цепи.

8. Вакуумный днод с большим углом пролета в качестве детектора и измерителя: мощности на СВЧ.

9. О зависимостях между частотой, углом, возвышением и расстоянием связи пріг распространенин коротких волн.

10. Зависнмость к.п.д. триодного усилителя мощности от напряжения питания.

11. Анализ сеточной цепи генераторного триода.

12. Согласование двух передатчнков, работающих на одну антенну с помоцью; Г-образной цепı.

13. Улучшение акустики актового зала пнститута.

14. Расчет и конструирование тиратрона.

Участие в конференции представителей других вузов и промышленных предприятий укрепило связь учебных заведений с промышленностью.

Конференция отчетливо показала, что научно-исследовательская работа должна сочетаться с производством и педагогической работой, что теория и практика неразрывны.

В 1957 г. тематика научно-исследовательских райот радиотехнического факультета была согласована с общегосударственным планом разьити науки и техннки ҚНР на ближайшие 12 лет и требованиями пронзводства.

В частності, кафедрами факультета были начаты научно-исследовательские работы по следуюшим темам:

1. Разработка телевнзнонной вещательной системы. В настояшее время уже разработаны синхрогенератор, система развертки, блоки формирования импульсов, источIIикн питання.

2. Измеренне параметров полупроводниковых прнборов. Разработана методика н3. мерения. Продолжаются исследования параметров различных типов полупроводниковых прнборов.

3. Исследование методов анализа линейных цепей. Исследовано применение преобразования Лапласа для линейных цепей. На заседаниях кафедры было заслушано три доклада по теме. 
4. Разработка опытного образца пмпульсного осциллографа. Работа проводилась с участием студентов, в соответствни с выдвннутым партией лозунгом «Создавать школы и ннституты на средства масс, сочетать учебу с работой».

5. Разработка опытного образца лампы оегущей волны. Работа проводилась в сочетан!и с дипломным проектированием. Предварительные нспытания лампы подтвердили правильность расчетов.

6. Разработка термисторов. Работа была связана с дипломным проектированием. Нзготовлены первые об́разцы термисторов.

7. Разработка методики проектірования мощных лучевых ламп. Методика использовалась в курсовом проектированни студентов IV курса по специальности «электронные и ионные прнборы». Сопоставленне проектов с реальными лампами подтвердино правнльность предложенной методики.

8. Разработка́ технологин нзготовления тиратрона с водородным наполнением. Работа проводится в сотрудничестве с Нанкинскнм заводом электронных и ионных лриборов. В настоящее время при участин студентов-дипломантов испытываются опытные образци ламп.

В 1958 г., кроме дальнейшего развитня указанных тем, начаты работы по приему слабых сигналов, исследованию трубок с накоплением зарядов, исследованню электрониого ирожектора с большими плотностями пучка, исследованию полупроводниковых пи:жнгателей нонных приборог и т.. .

Силами раднотехнического факультета при сотрудннчестве с Институтом радноэлектроники Академии наук КНР в нашем институте создана Нанкинская лаборатория радиюэ.лекроники. Органшзация .табораторин способствует дальнейшему развитию научн-исследовательской работы.

Декан радиотехнического факультета Нанкинского политехнического института

7 июня 1958 г. 